\title{
Editorial
}

\section{Um Organismo Vivo em Expansão: Grad+ Chega ao seu Quinto Número}

\author{
Prof. Thiago Mio Salla e Prof. Eder Cassola Molina
}

Depois de celebrar um ano de vida, a Revista de Graduação da USP (mais conhecida como Grad+) continua sua trajetória, ampliando, cada vez mais, o número de assuntos abordados, mas sem perder de vista seu escopo, qual seja, abrir espaço para pesquisas e práticas relacionadas ao ensino no âmbito da graduação. Tal como um organismo vivo e complexo que, por meio das relações de troca com o ambiente do qual faz parte, cresce e se desenvolve, o periódico expande-se em termos qualitativos e quantitativos. Ao todo, esta edição reúne oito artigos e vinte e um relatos, totalizando mais de duzentas páginas, algo inédito na curta, mas já prolífica trajetória da revista.

Quanto aos artigos, de modo a suprir uma lacuna, Grad+ abre espaço, pela primeira vez, ao ensino de Literatura. A capa da presente edição tem como mote o artigo "Aproximação de João Cabral" de autoria de Jean Pierre Chauvin (ECA/USP). Nesse texto, quem se faz presente é o autor de Educação pela Pedra, e, mais especificamente, as estratégias para estudá-lo em sala de aula. Para tanto, partindo da vasta fortuna crítica a respeito do poeta pernambucano, Chauvin procura discutir diferentes modos de analisar e interpretar a produção de tal artista, com vistas a despertar o interesse dos alunos para a beleza e a agudeza da poesia cabralina, na qual sobressaem, entre outros elementos, a sintaxe enxuta, a sonoridade telúrica e a sucessão de metáforas que expandem o imaginário do leitor, com destaque para o emprego de algumas figuras recorrentes, como o rio, a pedra e o sol.

Em seguida, Ana Paula Seixas Gomes e Patrícia Pupin Mandrá apresentam os resultados de um rico estudo a respeito dos hábitos de leitura visando à formação acadêmica de estudantes do curso de Fonoaudiologia da FMRP/USP. A partir de tal investigação, feita com mais de cem estudantes, as autoras ressaltam a importância da internet como espaço preferencial de leitura para os graduandos em busca de conhecimento, ao mesmo tempo que revelam a baixa procura da parte deles por e-books, dissertações/teses na base da biblioteca virtual da USP e revistas eletrônicas.

Também de modo inédito, Grad+ concede espaço para a importância do trabalho voluntário e para as implicações de tal prática sobre o ensino superior e, mais especificamente, sobre a formação de profissionais de saúde. Em linhas gerais, as autoras de tal colaboração argumentam que o voluntariado se constitui em uma rica oportunidade de o aluno de graduação vivenciar a realidade de uma instituição e desenvolver, para além da relação profissional, os valores éticos e humanísticos de compromisso para com o outro, com ênfase no exercício da cidadania.

A pluralidade e a novidade continuam a dar o tom na seção de artigos. Graduandos e professores da Esalq/USP, a partir de uma iniciativa com abelhas jataís, procuram incrementar a educação ambiental do público infantil e, nesse processo, ampliar as possibilidades do magistério em ciências agrárias. Ao mesmo tempo, um pool de pesquisadores e docentes da FMZV/USP analisa a relevância do emprego de recursos tecnológicos no ensino de Anatomia Veterinária, com ênfase para a digitalização e a impressão 3D voltada para a produção de biomodelos dos esqueletos de cachorros e cavalos.

Ainda sobre tal segmento da revista, convém assinalar que ele abriga também trabalhos a respeito 1) do ensino de Ginástica, partindo da insuficiência de conhecimentos prévios sobre essa modalidade esportiva apresentados por discentes de Educação Física ao ingressarem na universidade; 2) do emprego do Problem-Based Learning Modified (PBLM) como estratégia didática para o ensino de radiologia 
básica na área de Odontologia; e 3) de uma proposta de revisão bibliográfica que procura discutir artigos publicados entre 2000 e 2014 sobre o uso das Tecnologias de Informação e Comunicação (TICs) como ferramenta didática, tendo em vista o melhor rendimento dos alunos.

Parte da vasta extensão do presente volume está diretamente relacionada à ampliação da seção de Relatos. A grande oferta, a qualidade e a importância dos originais submetidos à Grad + nos levaram a tomar essa decisão. Os mais de vinte textos recolhidos em tal espaço distinguem-se pela multiplicidade de pesquisas teóricas e empíricas, experiências pedagógicas e práticas de ensino compartilhadas com o leitor. Chamam ainda a atenção por contemplarem os mais diferentes campos do conhecimento e unidades da USP (mas há também colaborações oriundas de outras instituições de ensino superior).

De modo mais particular, em meio a tal conjunto de escritos, que versam sobre assuntos que vão desde o ensino de matemática por meio da internet até a abordagem da arte marcial chinesa como ferramenta de desenvolvimento humano, alguns se destacam. Déborah de Oliveira (FFLCH/USP) relata a experiência de um projeto situado no Parque CienTec/USP que trata, em chave lúdica e didática, das propriedades e da importância do solo e, assim, promove a articulação das três bases do tripé universitário. Da ECA/USP, por sua vez, provém uma iniciativa pioneira de avaliação discente feita no curso de Publicidade e Propaganda, tendo como base uma prévia e ampla discussão do Projeto Político-Pedagógico de tal habilitação. Além disso, temos o uso de uma estratégia didática de constituição de um "júri simulado" para discutir, entre outros aspectos, a dimensão jurídica da perda auditiva no curso de Fonoaudiologia da Faculdade de Odontologia de Bauru.

Enfim, pelo rápido resumo desta edição traçado acima, Grad+ segue firme em seu propósito de contemplar o múltiplo, mas sem nunca perder de vista a organicidade que a caracteriza desde o início de sua trajetória editorial. E tal gesto de conferir unidade ao disperso irmana-se com a nobre missão de trabalhar em favor do aperfeiçoamento de todas as facetas do ensino de graduação e, de modo mais específico, de valorizar a atividade docente livre e autônoma, pilar de sustentação da universidade. 